\title{
ECONOMIC AND FINANCIAL ASPECTS OF WATER MANAGEMENT IN THE DNIESTER BASIN (THE SECTOR OF THE REPUBLIC OF MOLDOVA)
}

\author{
Bacal Petru ${ }^{1}$, Boboc Nicolae ${ }^{2}$
}

Key words: water, management, Dniester, tariff, efficiency.

\begin{abstract}
The main topics presented in this paper are following:1 Essence and the tools of the economic mechanism of management of water resources; 2 Taxes on water consumption; 3 Tariffs for services of water supply and sewerage; 4 administrative penalties for infringements of use and protection of water resources; 5 The grants for the rational use and protection of water. In the Dniester Basin have been concentrated the majority of water resources, of urban, industrial and agricultural centers. Thus, this basin holds over $90 \%$ of water consumption, most of which are captured from surface sources and used by industrial enterprises from the left bank of Dniester, especially by Thermoelectric Plant (TEP) from Dnestrovsk. On the right bank of Dniester it is noted communal enterprises, agricultural and food industry, and in most of the localities water is captured from groundwater sources. Actual amount of water tax is very low, which conditioned the increased of water consumption and irrational use of these limited resources.
\end{abstract}

\section{Introduction}

The Dniester basin covers about two thirds of the surface of the country and contributes with over $90 \%$ of the total volume of captured and used waters, which is why the situation of this basin determines the general situation in Moldova. Over $80 \%$ of water are captured from surface sources and used by companies from left bank of Dniester (Transnistria), including over $70 \%$ by TEP from Dnestrovsk. On the right bank of Dniester are captured 166 million $\mathrm{m}^{3}$ (table 1), including 80 million $\mathrm{m}^{3}$ in Chisinau. Only in Dnestrovsk, Chisinau and Soroca towns over $90 \%$ of captured water is coming from surface

\footnotetext{
${ }^{1}$ Academy of Economic Studies of Moldova, p_bacal@yahoo.com

${ }^{2}$ Institute of Ecology and Geography of Science Academy of Moldova
} 
sources. In the other localities, including Tiraspol and Bender is captured groundwater, and the Dniester river and its tributaries made only receivers function of natural polluted wastewater. The main tributaries of the Dniester Raut, Bâc and Botna have a small share (4\%) and more $80 \%$ of water is captured from underground sources.

Tab. 1. Volume of captured water

\begin{tabular}{|c|c|c|c|c|c|}
\hline \multirow{3}{*}{$\begin{array}{l}\text { Hidrographical } \\
\text { Basins }\end{array}$} & \multicolumn{5}{|c|}{ The captured waters } \\
\hline & \multicolumn{2}{|l|}{ Total } & \multirow{2}{*}{ Surface sources, million $\mathbf{m}^{3}$} & \multicolumn{2}{|c|}{ Underground sources } \\
\hline & million $\mathbf{~ m}^{3}$ & $\%$ & & million $\mathbf{m}^{3}$ & $\%$ \\
\hline Dniester & 821 & 96 & 716 & 107 & 13 \\
\hline Dniesters riverbed & 222 & 26 & 150 & 72 & 32 \\
\hline Răut & 15,6 & 1,8 & 2,5 & 13,1 & 84 \\
\hline Răut riverbed & 4,6 & 0,5 & 0,37 & 4,2 & 91 \\
\hline Bâc & 8,3 & 1,0 & 0,20 & 8,0 & 96 \\
\hline Botna & 2,4 & 0,3 & 0,46 & 1,9 & 79 \\
\hline Republic of Moldova & 857 & 100 & 728 & 129 & 15 \\
\hline Whithout Transnistria & 166 & 19 & 113 & 52,6 & 32 \\
\hline Transnistria & 691 & 81 & 615 & 75,2 & 11 \\
\hline
\end{tabular}

Source: elaborated by author after data from [8]

The economic and sphere mechanism in the use and water protection is focused on some basic principles, such as: a) the beneficiary and the polluter pays; b) full recovery of costs related to the use of water; c) optimize economic performance, environmental and health sources and water supply facilities; d) decentralization and local financial autonomy; e) the rational use and protection of water resources; f) norming water consumption and wastewater discharge; g) to prevent accidental and critical situations.

The economic and financial instruments regulating the use of water resources are: 1) water consumption taxes levied on users primary who have their own installation sources and water catchment; 2) tariffs for water applied to secondary water users that are supplied by primary users and/or operators of water services and sanitation; 3) payments for pollution; 4) fines for infringements of use and protection of water and hydraulic engineering constructions; 5) damage caused by surface water and groundwater sources and water supply systems, sewerage networks and hydrotechnical installations; 6) grants for the expansion and modernization of water supply and sanitation.

\section{Water supply services}

In the Republic of Moldova water supply services are offered by:

1) Local companies of Association "Moldova Apa-Canal" for household and technological use, who contributes over $80 \%$ to water provision and $90 \%$ to sewerage and wastewater purification; 
2) Irrigation District Associations, infrastructure of them is mostly worn out and destroyed

3) Industrial enterprises, especially sugar factories, mining, building and energetics companies;

4) Water users associations from rural areas - for household, agriculture and irrigation uses;

5) Small enterprises or individuals that provide water supply services in rural areas.

The expansion of water supply infrastructure must be accompanied by a similar expansion of the sewerage network. These requirements were recently included in both the draft legislation regulating of this area, as well as regulations of the specialized companies of water supply and of environmental, social and regional funds, which finances such projects.

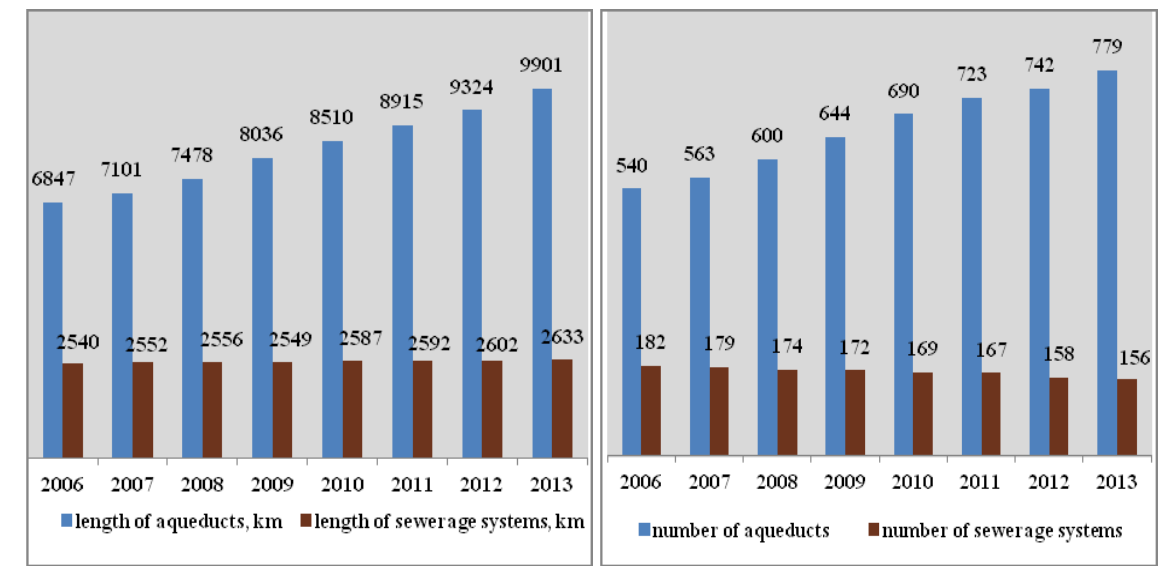

Fig. 1-2. The dynamics of aqueducts and sewerage systems in the Republic of Moldova

Despite their obligatory character, these requirements are not respected frequently in practice. In the years 2006-2013, aqueducts length increased by more than $2000 \mathrm{~km}(+54 \%)$ from $6847 \mathrm{~km}$ to $9901 \mathrm{~km}$ (fig. 1) and their number - from 540 to $779(+44 \%)$. At the same time, the length of sewage networks increased by less than $100 \mathrm{~km}(+4 \%)$ - from $2540 \mathrm{~km}$ to $2633 \mathrm{~km}$ [1], and their number decreased by $16 \%$, from 182 to 156 units (fig. 2). The coverage of water supply networks sewers decreased in the respective period from $34 \%$ to only $20 \%$. More than that, abandonment of sewage networks is observed, in most cases, in rural areas and mono-specialized small towns, 
which are in a process of intense ruralisation in the last two decades. Despite very active promotion of centralized water supply projects currently benefit from centralized systems only $1 \%$ of the rural population and only 16 villages of over 1500. This critical situation stimulates massive depopulation of rural space from Moldova and significantly limits the development of rural tourism, especially for the foreign visitors.

Tab.2. Development level of aqueducts and sewerage systems in the Republic of Moldova, $\%$

\begin{tabular}{|c|c|c|c|c|c|c|}
\hline \multirow{2}{*}{} & \multicolumn{2}{|c|}{ Total } & \multicolumn{2}{c|}{ Urban areas } & \multicolumn{2}{c|}{ Rural areas } \\
\cline { 2 - 7 } & aqueducts & sewerage & aqueducts & sewerage & aqueducts & sewerage \\
\hline Localities & 39 & 10 & 77 & 67 & 36 & 1 \\
\hline population & 42 & 21 & 69 & 50 & 23 & 1 \\
\hline
\end{tabular}

Sources: Figures 1-2 and table 2 are elaborated by author after data from statistica.md.

Water supply services in the Dniester Basin are provided almost entirely by 538 pumping stations with a total capacity by $681,000 \mathrm{~m}^{3} /$ day [6, p. 15-26]. The company "Apa-Canal Chisinau" has 185 wells (34\%), which can pump up to $440,000 \mathrm{~m}^{3} /$ day. Balti Municipality has 91 pumps with a summary capacity by $47,000 \mathrm{~m}^{3} /$ day. However, water supply Balti and Soroca several localities, Floreşti, Drocia and Râşcani is provided by the company " Acva-North" Soroca, which captures water from Dniester riverbed and capture capacity is up to 100 thousand $\mathrm{m}^{3} /$ day. In other localities (without Orhei and Soroca) capacity pumping stations does not exceed $10000 \mathrm{~m}^{3} /$ day. Because of massive economic decline during the transition period, currently only used by $30 \%$ of the capacity specified in the project documentation. In Chișinău it used only $62 \%$ of capacity and in the most other localities - up to $30 \%$.

The enterprises of Association "Moldova Apa-Canal" annually provides over 60 million $\mathrm{m}^{3}$ of water or about $50 \%$ of the total water used in the country and $80 \%$ of the Dniester basin. About 45 million $\mathrm{m}^{3}$ of water $(75 \%)$ of water supplied by the company "Apa-Canal Chisinau", 7,5 million. $\mathrm{m}^{3}(12 \%)-$ by Soroca „Acva-North" and 3,7 million $\mathrm{m}^{3}$ - by "Apa-Canal Balti". For the needs of the population are used 41 million $\mathrm{m}^{3}$ or $67 \%$ of the total water supplied, including in Chisinau - 34,8 million $\mathrm{m}^{3}(77 \%)$ and Balti $-2,9$ million $\mathrm{m}^{3}(78 \%)$. To economic agents are provided about 17 million $\mathrm{m}^{3}$ or $28 \%$ of the total water supplied, including by "Apa-Canal Chisinau" - 7,9 million $\mathrm{m}^{3}$ (18\%), Soroca " Acva-North " - 7,5 million m ${ }^{3}$ (99\%) and "Apa-Canal Balti" 912 thousand $\mathrm{m}^{3}(25 \%)$. For budgetary organizations provided about 3 million $\mathrm{m}^{3}$ or $5 \%$ of total water supplied, including in Chisinau $-2,4$ million $\mathrm{m}^{3}(5 \%)$ and Balti -229 thousand $\mathrm{m} 3(6 \%)$. 
The summary losses of captured water are on average $41 \%$ and are direct conditioned by similar wear degree $(43 \%)$ of water supply networks and sewerage. The maximum loss is registered in Rezina, Drochia and Străşeni, at the "Apa-Canal" Chisinau, Teleneşti, Orhei and Calarasi wear level of fixed assets exceeds $60 \%$.

\section{The tax for water consumption}

The tax for water consumption is apply to primary users, who capture surface water or groundwater, for the purposes of its own production activities, execution of works and provision of services. The tax for water is calculated by the payer, depending on the volume of water used, according to the data meters or under the rules of consumption of water [4]. They are subject predominantly by quantitative indices as well reserves of surface water and groundwater, the amount of atmospheric precipitations and hydrographic network density, technological aggregates and field of water use. Taxes on water consumption are transferred to the budget of the administrative-territorial units of second degree (districts and municipalities) being used, especially for the current financial assistance to local public works and services of first necessity.

At present, water tax is levied at the following rates: a) for every $1 \mathrm{~m}^{3}$ of water extracted from the water fund $-0,3$ lei; b) for each $1 \mathrm{~m}^{3}$ of natural mineral water extracted, for other water extracted designed to bottling - 16 lei; for water used from hydropower $-0,03$ lei $/ 10 \mathrm{~m}^{3}$.

The tax does not apply to: a) water extracted from underground simultaneously with useful minerals; b) water extracted and delivered to the population, public authorities and public institutions; c) water extracted for firefighting; d) water extracted from the enterprises of blinds, deaf, disabled and public medical institutions; e) water extracted or prison's institutions delivered to it.

Therefore, the current methodology for calculating the payments for water consumption is very simple and can easily be applied by beneficiaries. Despite its simplicity, the current methodology for calculating payments for water consumption contains a number of shortcomings: a) tax rates for water are not adjusted to inflation rate; b) the amount equal to $1 \mathrm{~m}^{3}$ of water from surface sources and for groundwater; c) is poorly reflected the assurance with water of territory; d) tax rates are not subject to value and price of water, but by reduced financial assurance; e) does not take into account the ecological status of surface water and of groundwater [2, p. 115]; f) the amount of payments for water does not express directly the costs for capturing and transporting of water; g) does not stimulate recirculation and saving of water; $h$ ) is not based on ecologic-economic appreciation of aquatic resources and river basins, 
according to Cadastral State Water; i) tax rates, depending on the water consumption, are not established on the river basin, but on the administrativeterritorial units; i) the application of this tax has only fiscal effects, but economical and ecological effects is very small.

Very low amount of payments for water use makes the overcoming of common rules consumption and increase the volume of discharge of waste water in majority branches of the economy, particularly, in the agriculture and in the food industry. Tax for water consumption should also include the costs of research on cost/benefit analysis, to determine a fair price and optimal variants and norms of use of drinking water, the water-courses and watersheds.

Annual water tax is more than 20 million MDL. Maximum tax revenues are found in mineral water bottling companies, followed by food industry and agricultural companies.

\section{Tariffs for water supply and sewerage service}

Tariffs for water supply and sewerage service are applied to secondary users, who are supplied by specialized public enterprises, especially of Association "Moldova Apa-Canal" or by other operators authorized to provide its services. Scope of water supply and sewerage services contains several key sectors: 1) population and households; 2) budgetary organizations; 3) economic agents (table 3), who performing various entrepreneurial activities and require a fee purchase of these services. The amount and application procedure of tariffs for public water supply are provided in Decision no. 164 of

Tab. 3. Tariffs for providing of water supply services by companies of Association "Moldova Apa-Canal" from Dniester Basin (average rate) in MDL/m3 (excluding VAT)

\begin{tabular}{|c|c|c|c|c|c|c|c|c|c|}
\hline Categories & $\mathbf{2 0 0 7}$ & $\mathbf{2 0 0 8}$ & $\mathbf{2 0 0 9}$ & $\mathbf{2 0 1 0}$ & $\mathbf{2 0 1 1}$ & $\mathbf{2 0 1 2}$ & $\mathbf{2 0 1 3}$ & average & $\begin{array}{c}\text { increase, } \\
\%\end{array}$ \\
\hline average tariff & 16,58 & 17,56 & 19,6 & 20,96 & 22,4 & 23,49 & 23,49 & 20,58 & 142 \\
\hline household & 11,0 & 11,6 & 13,2 & 15,3 & 17,0 & 18,0 & 18,0 & 14,88 & 163 \\
\hline $\begin{array}{c}\text { budgetary } \\
\text { organizations }\end{array}$ & 38,1 & 38,5 & 41,7 & 45,3 & 44,7 & 46,6 & 46,6 & 43,07 & 122 \\
\hline $\begin{array}{c}\text { economic } \\
\text { agents }\end{array}$ & 40,5 & 41,7 & 43,3 & 46,1 & 46,8 & 48,2 & 48,2 & 44,98 & 119 \\
\hline
\end{tabular}

Source: table 3, 4 are elaborated by author after data from [3], [6, p. 36-43]

National Agency for Energy Regulatory from 29.11.2004 on "Methodology of determination, approval and implementation of tariffs for public water supply, sewerage and wastewater treatment." Rates are calculated separately for providing with drinking and technological water, according to the spending necessary to deliver those services expressly stipulated in this Methodology 
[5]. The tariffs quotas for water supply and sewerage are established by municipal enterprises that provide these services and submitted for approval to the local public authorities.

The mechanism applied at the determining tariff is based on the following principles: 1) reliably providing of those services at real costs, needed for efficient use of production capacity of the company; 2) priority coverage costs and expenses to these charges; 3 ) performing an efficient activity that would give the company the opportunity to recover funds invested in production capacity.

Under the new provisions of Law no. 303 of 12.13.2013 on the public water supply and sewerage, if the local council approves a lower rates than those stipulated in the opinion delivered by the Agency, it shall establish in its decision of tariffs approving the concrete source and amount operator to be allocated from the local budget for covering lost revenues by operator due to approving of reduced tariffs.

The average amount (for 2007-2013 years) of general tariff for water supply services in the Dniester basin is $20,6 \mathrm{MDL}^{3} / \mathrm{m}^{3}$. These vary from 3,53 $\mathrm{MDL} / \mathrm{m} 3$ water released by company „Soroca Acva-North” until $33 \mathrm{MDL} / \mathrm{m} 3$ in Floresti. The maximum rates of over $25 \mathrm{MDL} / \mathrm{m}^{3}$ is registered at the enterprises located, mostly in the Dniester riverbed and Răut basin, including Ocniţa, Floresti, Donduseni, Drochia, Anenii-Noi, Căuşeni and Stefan-Voda [3]. The minimum rates are approved also in Şoldăneşti $\left(10,0 \mathrm{MDL} / \mathrm{m}^{3}\right)$, Chisinau $\left(10,6 / \mathrm{m}^{3}\right)$ and its suburbs (Floreni, Cricova and Ciorescu), which are supplied, at low prices, with water captured from Dniester riverbed from Vadul lui Voda station.

The lower rates of general tariff in Chisinau and Balti municipalities is explained by net superior "economies of scale" to those services, and crosssubsidization of tariffs for the population on account of higher revenues (about 3 times) from agencies economic and budgetary organizations (figure 5) located here in much higher numbers and which have a net water superior consumption to the other towns. Lower amount of the tariffs in some localities only is explained by provision of water supply and partially of the sewerage service without providing of water treatment services (Soroca, Criuleni), and by massive social pressure and political consensus in these local councils.

\footnotetext{
${ }^{3}$ in this period, 1 euro has varied between 14 and $19 \mathrm{MDL}$
} 
Table 4 The dynamic of tariffs for providing of water supply services by companies of Association "Moldova Apa-Canal" from Dniester Basin (average rate) in MDL $/ \mathrm{m}^{3}$ (excluding VAT)

\begin{tabular}{|l|l|c|c|c|c|c|c|c|c|c|}
\hline No. & Localities & $\mathbf{2 0 0 7}$ & $\mathbf{2 0 0 8}$ & $\mathbf{2 0 0 9}$ & $\mathbf{2 0 1 0}$ & $\mathbf{2 0 1 1}$ & $\mathbf{2 0 1 2}$ & $\mathbf{2 0 1 3}$ & average & increase, \\
\hline 1 & Ocniţa & 16,5 & 16,5 & 16,5 & 26,59 & 29,8 & 37,29 & 37,29 & 25,78 & 226 \\
\hline 2 & Donduşeni & 18,08 & 18,08 & 19,67 & 19,67 & 19,67 & 27,2 & 27,2 & 21,37 & 150 \\
\hline 3 & Drochia & 25,56 & 25,56 & 25,56 & 30,16 & 30,16 & 30,16 & 30,16 & 28,19 & 118 \\
\hline 4 & Soroca & 14,57 & 14,57 & 20,21 & 20,21 & 19,38 & 19,38 & 19,38 & 18,24 & 133 \\
\hline 5 & Acva Nord & 3,56 & 3,56 & 3,56 & 2,99 & 3,68 & 3,68 & 3,68 & 3,53 & 103 \\
\hline 6 & Floreşti & 28,2 & 32,2 & 32,2 & 32,2 & 35,26 & 35,26 & 35,26 & 32,94 & 125 \\
\hline 7 & Râşcani & 26,52 & 26,52 & 26,44 & 26,44 & 26,44 & 27,04 & 27,04 & 26,63 & 102 \\
\hline 8 & Bălţi & 16,72 & 16,72 & 16,72 & 19,91 & 23,32 & 23,32 & 23,32 & 20,00 & 139 \\
\hline 9 & Sângerei & 11,97 & 11,97 & 11,97 & 13,74 & 20,05 & 20,05 & 20,05 & 15,69 & 168 \\
\hline 10 & Şoldăneşti & 9,1 & 9,1 & 9,1 & 9,1 & 11,1 & 11,1 & 11,1 & 9,96 & 122 \\
\hline 11 & Rezina & 9,46 & 9,46 & 14,29 & 20,43 & 20,43 & 26,65 & 26,65 & 18,20 & 282 \\
\hline 12 & Teleneşti & 25,39 & 25,39 & 27,74 & 27,74 & 27,74 & 27,74 & 27,74 & 27,07 & 109 \\
\hline 13 & Orhei & 23,74 & 23,74 & 23,74 & 23,74 & 28,81 & 28,81 & 28,81 & 25,91 & 121 \\
\hline 14 & Criuleni & 19,9 & 19,9 & 19,9 & 19,9 & 19,9 & 19,9 & 19,9 & 19,90 & 100 \\
\hline 15 & Anenii Noi & 24,18 & 24,18 & 30,29 & 30,29 & 30,29 & 37,55 & 37,55 & 30,62 & 155 \\
\hline 16 & Străşeni & 13,65 & 26,2 & 26,2 & 26,2 & 26,2 & 26,2 & 26,2 & 24,41 & 192 \\
\hline 17 & Cojuşna & 17,0 & 8,0 & 16,05 & 16,05 & 16,05 & 16,05 & 16,05 & 15,04 & 94 \\
\hline 18 & Călăraşi & 13,14 & 13,14 & 18,08 & 24,71 & 26,69 & 26,69 & 26,69 & 21,31 & 203 \\
\hline 19 & Chişinău & 8,42 & 8,42 & 8,42 & 12,17 & 12,17 & 12,17 & 12,17 & 10,56 & 145 \\
\hline 20 & Stăuceni & 6,45 & & & & & & & 6,45 & 0 \\
\hline 21 & Cricova & 12,0 & 12,0 & 20,2 & 20,2 & 25,35 & 25,35 & 25,35 & 20,06 & 211 \\
\hline 22 & Ciorescu & 12,34 & 16,05 & 16,05 & 16,05 & 17,05 & 17,05 & 17,05 & 15,95 & 138 \\
\hline 23 & Floreni & 7,21 & 7,21 & 7,21 & 13,18 & 14,37 & 14,37 & 14,37 & 11,13 & 199 \\
\hline 24 & Căuşeni & 24,38 & 25,57 & 25,57 & 25,57 & 29,15 & 33,18 & 33,18 & 28,09 & 136 \\
\hline 25 & Ştefan Vodă & 26,28 & 26,28 & 31,53 & 31,53 & 31,26 & 31,26 & 31,26 & 29,91 & 119 \\
\hline & Dniester basin & $\mathbf{1 6 , 5 8}$ & $\mathbf{1 7 , 5 6}$ & $\mathbf{1 9 , 6}$ & $\mathbf{2 0 , 9 6}$ & $\mathbf{2 2 , 4}$ & $\mathbf{2 3 , 4 9}$ & $\mathbf{2 3 , 4 9}$ & $\mathbf{2 0 , 5 8}$ & $\mathbf{1 4 2}$ \\
\hline
\end{tabular}

The maximum tariff in some regional centers such as Floresti, Căuşeni, Stefan-Voda or Teleneşti [3], [6, p. 36-43] be explained by the fact that municipal enterprises in these localities, besides water supply and sewerage services renders and sanitation services and disposal of households waste, for which pay only a small share of the population. To offset expenses and lost revenues from these services and the maintenance of green spaces, these enterprises set higher tariffs for services of water supply and sanitation, which is a much higher subscriber of the local population. For this reason, some companies of the Association "Moldova Apa-Canal" had a negative return, despite the fact that tariffs s set covers almost all costs of water supply services and sanitation. 
The growth of tariffs for water supply of population and households is higher $(63 \%)$ than for budgetary organizations $(22 \%)$ and businesses $(19 \%)$. Thus, in the most communal enterprises from the Dniester basin tariffs for water supply of economic agents recorded a slight increase (up to 15\%) and significantly lower than those growth for the population, which demonstrates once again about promoting uniform tariff policy for all categories of water consumers and the abolition of cross-subsidization. Despite those changes positive, a significant number of economic and budgetary organizations disconnect from the centralized water supply and build your own capture and supply system. However, due to very low amount of payments for discharge wastewater (established in the mid-90s and still not adjusted to inflation and current prices) municipal the sewerage network, these consumers prefer not to use their systems for wastewater treatment and benefits at low prices, municipal treatment plants services that are not originally designed for industrial wastewater. As a result, most of the wastewater discharged into natural waters are insufficiently treated and seriously affect aquatic ecosystems and the human body.

Despite of recent significant increase of tariffs for water supply, its level is lower than those prime-cost at most enterprises, who work in this domain [6, p. 75,80$]$, and the average difference is about $1 \mathrm{MDL} / \mathrm{m}^{3}\left(13 \mathrm{MDL} / \mathrm{m}^{3}\right.$ towards $\left.14 \mathrm{MDL} / \mathrm{m}^{3}\right)$. Positive difference is observed only in Chisinau $\left(1,4 \mathrm{MDL} / \mathrm{m}^{3}\right)$ and its suburbs Ciorescu and Cricova, and in Râşcani, Drochia, Sângerei, Ocniţa, Balti and Stefan-Voda towns. At the rest enterprises prime costs exceed those tariffs. In the 2012-2013 years, due to higher growth rates of tariffs and slower growth of prime costs is observed removinf of this difference at enterprises from Donduseni, Rezina, Anenii-Noi and Căuşeni.

Starting with second half of 2013, due to the rapid depreciation of the national currency, the rapid growth of expenditures for materials, especially for fuel, reducing the difference between the tariff rate and prime costs decreased considerably. In addition, any increase of electricity tariff, will condition faster growth of prime costs and even increase of those differences. Moreover, the increase in electricity tariffs and fuel price that is not within the competence of local authorities is accepted more easily than increase of tariffs for public utilities, including water supply and sanitation. For this reason, the application (from 14.09.2014) the new provisions of Law no. 303 of 12.13 .2013 on the public water supply and sanitation on the compulsory cover of the expenditures from tariff of these service will be very difficult, especially before near election period. 
Administrative sanctions for violation of legislation of use and protection of water resources

Fines for water pollution have been well known in Soviet times, especially for people with responsible positions, which were harshly penalized for dangerous spread of microbiological pollutants in water supply sources, massive population of infection. Until 2009, the absolute majority of the fines

Table 5. Fines for violation of water legislation in the Dniester basin

\begin{tabular}{|c|c|c|c|c|c|c|c|c|c|c|c|c|c|c|c|}
\hline \multirow{3}{*}{$\begin{array}{l}\text { Article of } \\
\text { Offences } \\
\text { Code }\end{array}$} & \multirow{2}{*}{\multicolumn{5}{|c|}{ Number of fines }} & \multicolumn{8}{|c|}{ The sum of applied fines } & \multicolumn{2}{|c|}{\begin{tabular}{|c|} 
The sum \\
of \\
collected \\
fines
\end{tabular}} \\
\hline & & & & & & \multicolumn{10}{|c|}{ thousand MDL } \\
\hline & 2009 & 2010 & 2011 & 2012 & 2013 & 2009 & 2010 & 2011 & 2012 & 2013 & 2009 & 2010 & 2011 & 2012 & 2013 \\
\hline 109.1 & 47 & 62 & 136 & 147 & 412 & 29,2 & 41,2 & 73,5 & 87 & 211 & 14,8 & 20,8 & 32,2 & 37,7 & 85 \\
\hline 109.2 & 7 & 42 & 10 & 12 & 17 & 12,8 & 35 & 8,2 & 10,4 & 33 & 6,6 & 16,5 & 4 & 4,8 & 16,5 \\
\hline 109.3 & 23 & 74 & 34 & 34 & 47 & 20,8 & 34,7 & 24,5 & 25,7 & 31,7 & 6 & 12,2 & 4,3 & 11,5 & 15,6 \\
\hline 109.4 & 16 & 83 & 154 & 142 & 132 & 2,2 & 18,9 & 31,9 & 35,9 & 43,4 & 1,7 & 8,7 & 15,1 & 18 & 23,6 \\
\hline 109.5 & 0 & 1 & 0 & 0 & 0 & 0 & 0,2 & 0 & 0 & 0 & 0 & 0,1 & 0 & 0 & 0 \\
\hline 109 & 93 & 262 & 353 & 335 & 608 & 65 & 130 & 151 & 159 & 320 & 29,1 & 58,2 & 61 & 71,5 & 141 \\
\hline 110.1 & 8 & 14 & 15 & 40 & 38 & 4,4 & 18,6 & 18,4 & 43,6 & 131 & 2,2 & 9,5 & 5,2 & 18 & 58,4 \\
\hline 110.2 & 12 & 24 & 33 & 36 & 57 & 33,8 & 78,8 & 68,4 & 119 & 219 & 16,7 & 35 & 30,2 & 59,7 & 94,2 \\
\hline 110 & 20 & 38 & 48 & 76 & 95 & 38,2 & 97,4 & 86,8 & 163 & 350 & 18,9 & 44,5 & 35,4 & 77,7 & 153 \\
\hline 111 & 13 & 26 & 16 & 32 & 38 & 2,9 & 9,5 & 11,2 & 29 & 22,8 & 1,6 & 5 & 5,6 & 15,5 & 12,1 \\
\hline 112 & 3 & 8 & 3 & 2 & 6 & 5 & 7,2 & 5 & 1 & 6,4 & 2,5 & 3,6 & 2,5 & 0,5 & 3,2 \\
\hline 113.1 & 3 & 10 & 9 & 43 & 13 & 18 & 30,4 & 27 & 66,8 & 38,6 & 6 & 16,4 & 11,3 & 35,7 & 19,2 \\
\hline 113.2 & 2 & 3 & 3 & 0 & 4 & 1,6 & 10,6 & 2,2 & 0 & 2,8 & 0,8 & 0,3 & 1,1 & 0 & 1,4 \\
\hline 113.3 & 5 & 5 & 2 & 2 & 3 & 4 & 3,6 & 7 & 1,6 & 9,8 & 2 & 1,8 & 0,5 & 0,8 & 5,4 \\
\hline 113.4 & 1 & 0 & 4 & 0 & 1 & 0,6 & 0 & 2 & 0 & 0,6 & 0,3 & 0 & 1 & 0 & 0,3 \\
\hline 113.5 & 1 & 1 & 10 & 2 & 2 & 6 & 1 & 11,8 & 6,6 & 12 & 3 & 0,5 & 5,3 & 3,3 & 6 \\
\hline 113 & 12 & 19 & 28 & 47 & 23 & 30,2 & 45,6 & 50 & 75 & 63,8 & 12,1 & 19 & 19,2 & 39,8 & 32,2 \\
\hline 143 & 13 & 35 & 60 & 11 & 128 & 8,8 & 24,9 & 40,1 & 7,4 & 79,3 & 4,1 & 13,5 & 18,8 & 3,7 & 42 \\
\hline 144 & 7 & 6 & 13 & 16 & 36 & 2,4 & 11,2 & 25,6 & 27,2 & 53,8 & 1,2 & 1,4 & 7,5 & 13,2 & 22,8 \\
\hline 149 & 0 & 13 & 4 & 3 & 1 & 0 & 22,8 & 9,2 & 7,8 & 10 & 0 & 11,4 & 4,6 & 0,4 & 0 \\
\hline 156 & 21 & 59 & 27 & 31 & 91 & 69,3 & 144 & 67,6 & 90 & 265 & 34,4 & 67 & 38,3 & 43,5 & 137 \\
\hline 170 & 3 & 4 & 8 & 50 & 46 & 3 & 9,6 & 6,5 & 124 & 73,2 & 1 & 4,3 & 6 & 17,8 & 33,2 \\
\hline 171 & 2 & 3 & 2 & 0 & 21 & 2 & 2,6 & 2 & 0 & 18 & 0 & 0,5 & 0,8 & 0 & 9 \\
\hline 176 & 0 & 1 & 1 & 6 & 3 & 0 & 0,2 & 0,2 & 2,4 & 1,2 & 0 & 0,1 & 0,1 & 0,8 & 0 \\
\hline Total & 460 & 480 & 581 & 915 & 1110 & 238 & 516 & 463 & 688 & 1294 & 106 & 231 & 203 & 286 & 592 \\
\hline
\end{tabular}

Source: table 5 is elaborated by author after data from $[9,10]$

in this area was applied for violation of state ownership of water (art. 59.1) and for many offences, especially for those causing massive pollution and the degradation of water protection zones, were not provided administrative sanctions. Under the new Offences Code, the number of penalties imposed for not complying with legislation of use and protection has increased considerably and adjusted to the basic provisions of legislation in this field. As 
a result, in the 2009-2013 years it is found 2-time increases of fines number and 5-time of sum of imposed and collected fines for violation of water legislation (table 5).

In recent years, most of the fines are imposed for offenses of general application area, such as (table 5): non-compliance of water protection normative, which resulted in water pollution or soil erosion; (art. 109.1); failure dimensions and regime protection of water protection areas of rivers and water basins (art. 109.4); washing vehicles in natural waters (art. 109.3); violating the rules of water usage (article. 110); failure to comply with legal provisions of State Ecological Expertise and Environmental Impact Assessment (art. 156); non-payment for water pollution (art. 143).

In the same time, is found the rare application of fines for: applications of pesticides in rivers protected areas (art. 113.1); location in the water protection areas of the deposits of chemicals, fuel stations, stations for technical service and failure dimensions and regime protection of water protection areas of rivers and water basins washing of vehicle, sewerage systems and treatment plants (art. 113.2); (art. 109.4, 109.5); land processing, organizing camps for animals and camping sites in these areas (art. 113.4); discharge of untreated wastewater in Dniester rivers and its tributaries (art. 113.5); violation of hydro-technical requires (art. 170-176). Also, is not applied the cessation of economic activity of enterprises that seriously violates the law of use and protection of water.

\section{Subvention for protection of water resources}

In the majority of territorial-administrative units from Dniester basin is found an oscillated evolution of the number of financed projects and amounts of money allocated for their implementation. This situation was largely conditioned by the reduced number of applicants with high professional abilities, by the level of their cooperation with the ecological authorities, as well as by some political criteria. Thus, until 2009, predominates projects which involving small and medium cost, which can be co-financed lighter and are designed to the execution of separate works. Also, most projects in this field have been funded for expansion and modernization of the centralized potable water provision, for construction and arrangement of wells and springs in rural areas, for cleaning of small rivers and for arrangement of protection areas of water objectives.

As a result of increasing of financial resources accumulated in NEF, in recent years there has been a considerable increase of the amounts allocated for sewerage and complex projects, starting the capital construction and reconstruction of municipal treatment plants. This multiple increase is directly 
conditioned by similar increases of the received payments for imports of goods that cause environmental pollution, especially oil products, tetra-pack containers and cars.

Table 6 The priority financing directions of the National Environmental Fund (NEF) in the Dniester basin, in million MDL

\begin{tabular}{|l|c|c|c|c|c|c|c|c|c|c|c|}
\hline Directions of & \multicolumn{10}{|c|}{ Years } \\
\cline { 2 - 12 } \\
financing & $\mathbf{2 0 0 4}$ & $\mathbf{2 0 0 5}$ & $\mathbf{2 0 0 6}$ & $\mathbf{2 0 0 7}$ & $\mathbf{2 0 0 8}$ & $\mathbf{2 0 0 9}$ & $\mathbf{2 0 1 0}$ & $\mathbf{2 0 1 1}$ & $\mathbf{2 0 1 2}$ & $\mathbf{2 0 1 3}$ & $\mathbf{2 0 1 4}$ \\
\hline $\begin{array}{l}\text { Water supply } \\
\text { and sewerage }\end{array}$ & $\begin{array}{c}6,6 \\
(64)\end{array}$ & $\begin{array}{c}9,1 \\
(90)\end{array}$ & $\begin{array}{c}17,5 \\
(95)\end{array}$ & $\begin{array}{c}17,2 \\
(58)\end{array}$ & $\begin{array}{c}21,8 \\
(51)\end{array}$ & $\begin{array}{c}36,4 \\
(59)\end{array}$ & $\begin{array}{c}56 \\
(58)\end{array}$ & $\begin{array}{c}88 \\
(77)\end{array}$ & $\begin{array}{c}98,6 \\
(73)\end{array}$ & $\begin{array}{c}194 \\
(113)\end{array}$ & $\begin{array}{c}175 \\
(116)\end{array}$ \\
\hline $\begin{array}{l}\text { Hidrotehnical } \\
\text { measures }\end{array}$ & $\begin{array}{c}0,09 \\
(2)\end{array}$ & $\begin{array}{c}(3), \\
(3)\end{array}$ & $\begin{array}{c}2,4 \\
(10)\end{array}$ & $\begin{array}{c}2,8 \\
(5)\end{array}$ & $\begin{array}{c}0,94 \\
(4)\end{array}$ & $\begin{array}{c}13,4 \\
(2)\end{array}$ & $\begin{array}{c}32 \\
(15)\end{array}$ & $\begin{array}{c}28,4 \\
(10)\end{array}$ & $\begin{array}{c}18,3 \\
(6)\end{array}$ & $\begin{array}{c}40,9 \\
(10)\end{array}$ & $9,3(3)$ \\
\hline $\begin{array}{l}\text { Greening of } \\
\text { the localities }\end{array}$ & 0,5 & 0,7 & 3,6 & 10,7 & 2,1 & 2,9 & 2,8 & 4,0 & 3,0 & 4,0 & $3,1(13)$ \\
\hline $\begin{array}{l}\text { Waste } \\
\text { management }\end{array}$ & $\begin{array}{c}1,3 \\
(20)\end{array}$ & $\begin{array}{c}0,65 \\
(9)\end{array}$ & $\begin{array}{c}4,2 \\
(23)\end{array}$ & $\begin{array}{c}2,0 \\
(19)\end{array}$ & $\begin{array}{c}5,0 \\
(21)\end{array}$ & $2,6(8)$ & $\begin{array}{c}7,2 \\
(11)\end{array}$ & $\begin{array}{c}13,8 \\
(8)\end{array}$ & $\begin{array}{c}17,2 \\
(10)\end{array}$ & $\begin{array}{c}20,8 \\
(8)\end{array}$ & $4,5(5)$ \\
\hline Other & $0,1(2)$ & $\begin{array}{c}0,4 \\
(4)\end{array}$ & $0,8(8)$ & $1,1(8)$ & $0,3(6)$ & $0,3(6)$ & $\begin{array}{c}14 \\
(31)\end{array}$ & $\begin{array}{c}5,8 \\
(26)\end{array}$ & $\begin{array}{c}6 \\
(44)\end{array}$ & $\begin{array}{c}11 \\
(45)\end{array}$ & $\begin{array}{c}13 \\
(16)\end{array}$ \\
\hline
\end{tabular}

The subsidies allocated to hydro-technical measures, especially for combating the consequences of natural disasters have benefited the districts, which are located in the lower course of the Dniester river (Criuleni, AneniiNoi and Ștefan-Voda), and have most suffered from floods of 2008 and 2010 years.

\section{Conclusions:}

1. Dniester basin contributes over $90 \%$ of the total volume of captured and used water in the Republic.

2. The absolute majority of localities on both banks of Dniester are supplied from groundwater sources and Dniester River and its tributaries only natural receiver function performs discharged wastewater.

3. In most rural localities, the extension of water supply network was not accompanied by the necessary work of sewage and waste water purification, which increased significantly impact on water and human health in these areas.

4. There are major gaps in the monitoring of water used and discharged, official statistics provided by the Agency „Apele Moldovei” are incomplete and the actual harmfulness of waste water evacuated is greater

\footnotetext{
${ }^{4}$ The first half of this year

${ }^{5}$ In parentheses is indicated the number of approved projects
} 
5. Despite the unique methodology of calculation of tariffs, we find large differences (up to 6 times) between the minimum and maximum rates approved by local councils, which proves us about the major influence of political factor

6. In most companies of Association "Moldova Apă-Canal" located in the Dniester basin the tariffs for water supply are under those prime costs, and rentability is negative.

7. It is necessary to adjustment of taxes and tariffs for water to inflation rate, the real cost of water supply, of discharge and purification of wastewater and to the ecological status of water resources and human health in the territory.

8. As a result of increasing financial resources accumulated in FEN, in recent years there has been a considerable increase of the amounts allocated for sewerage and complex projects, starting the capital construction and reconstruction of municipal treatment plants

\section{References}

Bacal P. (2010). Gestiunea protecţiei mediului înconjurător în Republica Moldova. Aspecte teoretice și aplicative. Chişinău: ASEM, 2010, 240 p.

*** Activitatea sistemelor de alimentare cu apă şi de canalizare în anii 2006-2013. In: statistica.md.

*** Buletinul informativ privind tarifele pentru serviciile de aprovizionare cu apă şi canalizare. In: amac.md.

*** Codul Fiscal al Republicii Moldova (nr. 67 din 05.05.2005). Titlul VIII. Taxele pentru resursele naturale. In: Monitorul Oficial nr. 080 from 10.06.2005.

*** Hotărârea nr. 164 a Agenției Naționale pentru Reglementare Energetică din 29.11.2004 privind Metodologia determinării, aprobării şi aplicării tarifelor pentru serviciile publice de alimentare cu apă, de canalizare şi epurare a apelor uzate. In: Monitorul Oficial nr. 218-223 from 03.12.2004

*** Indicii financiari şi de producție ai activităţii întreprinderilor de alimentare cu apă şi canalizare ale Asociației ,,Moldova Apă-Canal”. Chişinău, 117 p (2012)..

*** Informaţia Fondului Ecologic Naţional privind finanţarea proiectelor de mediu in anii 2004-2014.

*** Rapoartele anuale generalizate privind Indicii de gospodărire a apelor în Republica Moldova. Direcţia bazinieră a Agenţiei,,Apele Moldovei”. (20032013).

*** Rapoartele anuale privind calitatea factorilor de mediu şi activitatea Agenţiilor şi Inspecţiilor Ecologice (2003-2013).

*** Rapoartele Biroului Naţional de Statistică privind aplicarea sancţiunilor administrative în anii 2009-2014 